\title{
Androgen Binding Proteins of Testis, Epididymis, and Plasma in Man and Monkey
}

\author{
Robert A. Vigersky, D. Lynn Loriaux, Stuart S. Howards, Gary B. Hodgen, \\ MORTIMER B. LiPSETT, and ANDREAS CHRAMBACH
}

\begin{abstract}
From the Reproduction Research Branch, National Institute of Child Health and Human Development, National Institutes of Health, Bethesda, Maryland 20014 and Department of Urology and Physiology, University of Virginia Medical School, Charlottesville, Virginia 22904
\end{abstract}

\begin{abstract}
A B S T R A C T Androgen-binding protein (ABP) has been found in the cytosol of testicular and epididymal homogenates of several sub-primate species. In those species which had the plasma androgen binding protein, testosterone-estradiol-binding globulin (TeBG), ABP and TeBG were found to be physically similar. We investigated the possibility that $A B P$ might exist in monkey and man using the cytosol of testicular and epididymal homogenates and aspirates obtained by direct micropuncture of the rete testis. In polyacrylamide gel electrophoresis, $\mathrm{pH} 7.8$, testicular and epididymal cytosols of monkey and man were found to contain several binding proteins of different size and net charge that bind dihydrotestosterone. These binding proteins were either indistinguishable from TeBG or could be related to TeBG as size and/ or charge isomers. No ABP was detectable in up to $200 \mu \mathrm{l}$ of monkey rete testis fluid obtained by direct micropuncture, though ABP is detectable in as little as $5 \mu \mathrm{l}$ of rat rete testis fluid. The data suggest that the ABP's detected in the testicular and epididymal cytosols in monkey and man represent isomeric forms of plasma TeBG, and their presence in testicular cytosol most likely derives from blood contamination.
\end{abstract}

\section{INTRODUCTION}

An androgen-binding protein $(\mathrm{ABP})^{1}$ has been shown to exist in the testis and epididymis of the rat,

This work was presented in part at the 56th Annual Meeting of the Endocrine Society, Atlanta, Georgia, 1974. A preliminary report has appeared in abstract form: Vigersky, R. A., 1974 Human androgen binding proteins: physical properties. Endocrinology. 94: A-200.

Received for publication 16 December 1974 and in revised form 26 July 1976.

'Abbreviations used in this paper: ABP, androgen-binding protein; DHT, dihydrotestosterone; IFPA, isoelectric focus- rabbit, bull, and ram (1). In the rat and rabbit it appears that ABP is produced in the testis and secreted into the epididymis via the ductuli efferentes $(2,3)$. This protein was shown to be heat: stable at $50^{\circ} \mathrm{C}$, to bind dihydrotestosterone (DHT) with high affinity $\left(K_{d}=5.5 \mathrm{nmol} /\right.$ liter $)$ and to have a mol wt of $86,000-$ $91,000(4,5)$. These properties also characterize a plasma ABP, testosterone-estradiol-binding globulin (TeBG), that does not occur in the rat but does occur in most other speices, including man (6). When rat $A B P$ and human TeBG (4) or rabbit $A B P$ and rabbit TeBG (7) have been compared, marked similarity has been noted.

$\mathrm{ABP}$ in primates has not been previously described. Man and monkey both have TeBG, complicating the demonstration of a testicular or epididymal ABP in these species. In addition, limited availability of human material has made extensive study difficult. This paper presents evidence suggesting that a testicular ABP, separate from plasma TeBG, does not exist in man and rhesus monkey.

In this paper, $A B P$ refers to any protein(s) in the testis and/or epididymis capable of binding DHT, and TeBG refers to the plasma protein that binds DHT.

\section{METHODS}

Sources and Preparation of $A B P$. Adult human testis and/or epididymis specimens were obtained by orchiectomy, surgical biopsy, or autopsy. The diagnoses and the time between surgery or death and analysis are shown in Table I. Plasma was obtained by venipuncture from five normal subjects. Adult rhesus monkeys weighing approximately 10 $\mathrm{kg}$ were anesthetized with sodium pentothal, and unilateral orchiectomy was performed. Sexually mature Sprague-

ing in polyacrylamide gel; PAGE, polyacrylamide gel electrophoresis; \% $\mathrm{C}$, percentage of cross-linking; \% $\mathrm{T}$, percentage of total gel concentration; RTF, rete testis fluid; TeBG, testosterone-estradiol binding globulin. 
TABLE I

Clinical Features of Patients

\begin{tabular}{|c|c|c|c|c|c|}
\hline \multirow[b]{2}{*}{ Patient } & \multicolumn{2}{|c|}{ Ellipse number } & \multirow[b]{2}{*}{ Age } & \multirow[b]{2}{*}{ Histologic diagnosis or cause of death } & \multirow{2}{*}{$\begin{array}{l}\text { Time between biopsy } \\
\text { or death and analysis }\end{array}$} \\
\hline & Testis & Epididymis & & & \\
\hline & & & $y r$ & & $h$ \\
\hline W. D. & 6 & 7 & 55 & Pulmonary embolus & 14 \\
\hline H. J. & ND & ND & 71 & Alcoholic liver disease & 24 \\
\hline W. B. & 2 & $\mathrm{X}$ & 62 & Arterisclerotic cardiovascular disease & $<1$ \\
\hline R. J. & 8 & $\mathrm{X}$ & 24 & Bilateral cystic degeneration of vas deferens & $<1$ \\
\hline A. B. & 9 & $\mathrm{X}$ & 18 & Viral encephalitis & 6 \\
\hline \multirow[t]{2}{*}{ M. M. } & $10^{a}$ & & & & \\
\hline & $10^{b}$ & 11 & 66 & Scrotal carcinoma & $<1$ \\
\hline A. M. & 5 & $\mathrm{X}$ & 77 & Prostatic carcinoma & $<1$ \\
\hline R. S. & 3 & 4 & 25 & Seminoma & $<1$ \\
\hline W. S. & ND & ND & 27 & Sertoli cell only syndrome & $<1$ \\
\hline
\end{tabular}

" $\mathrm{X}$ " indicates that the tissue was not analyzed.

Dawley rats were anesthetized with ether, and bilateral orchiectomy was performed.

Tissues were immediately placed in $10 \mathrm{mM}$ Tris-chloride buffer, pH 7.4. The procedure of Ritzén et al. at $0^{\circ} \mathrm{C}(4)$ was used to prepare samples for electrophoresis. The protein concentration of the cytosol was determined with albumin as standard by the method of Lowry et al. (8). To remove endogenous steroid $(9,10)$ and precipitate androgen cytosol receptors $(11,12)$, dry charcoal (Norit A, American Norit Co., Jacksonville, Fla.) ( $1 \mathrm{mg} / \mathrm{mg}$ of protein) was added to the cytosol, and was allowed to incubate overnight at $4^{\circ} \mathrm{C}$. This procedure removes $99.5 \%$ of $\left[{ }^{3} \mathrm{H}\right]$ DHT from the cytosol. The charcoal was removed by three centrifugations at $10,000 \mathrm{~g}$ for $10 \mathrm{~min}$. The resulting supernatant was divided into aliquots corresponding to $400 \mu \mathrm{g}$ of protein, preincubated with approximately $100,000 \mathrm{cpm}$ $(800 \mathrm{pg})$ of $\left[1,2,-{ }^{3} \mathrm{H}\right]$ dihydrotestosterone (17 $\beta$-hydroxy- $5 \alpha$ androstan-3-one) ([ $\left.\left.{ }^{3} \mathrm{H}\right] \mathrm{DHT}\right)(\mathrm{sp}$ act $44 \mathrm{Ci} / \mathrm{mmol})$ for $1 \mathrm{~h}$ at $4^{\circ} \mathrm{C}$, and analyzed.

Metabolism of $\left[{ }^{3} \mathrm{H}\right] D H T$ by cytosol. To determine the amount of conversion of DHT to $5 \alpha$-androstanediol ( $5 \alpha$-androstan- $3 \alpha, 17 \beta$-diol or $5 \alpha$-androstan- $3 \beta, 17 \beta$-diol) during the incubation procedure, $10^{6} \mathrm{cpm}$ of $\left[{ }^{3} \mathrm{H}\right] \mathrm{DHT}$ was incubated at $4^{\circ} \mathrm{C}$ with $100 \mu$ l of testicular cytosol. At 1, 2, 3, 4, 5 , and $6 \mathrm{~h}, 10 \mu \mathrm{l}$ of cytosol was removed, diluted to 500 $\mu$ l with Tris-chloride buffer, $\mathrm{pH} 7.4$, and extracted twice with 5 vol of ether. The ether extracts were pooled and dried under a stream of air in a $30^{\circ} \mathrm{C}$ water bath. The residue was taken up in $100 \mu \mathrm{l}$ of methanol and applied to a precoated thin-layer plate (silica gel F 254, 0.25 mm, Merck AG, Inc., Darmstadt, W. Germany). The plates were developed in benzene:ethyl acetate::1:9. 1-cm sections of the silica gel were loosened with a razor blade and aspirated by vacuum into a Pasteur pipette plugged with glass wool. The radioactivity was eluted with $4 \mathrm{ml}$ of methanol, dried and redissolved in $1 \mathrm{ml}$ of methanol, and counted in $10 \mathrm{ml}$ of LSC complete scintillation fluid (Yorktown Research Inc., S. Hackensack, N. J.). The $R_{f}$ of DHT and $5 \alpha$-androstanediol standards were 0.722 and 0.611 , respectively.

The relative amount of the $3 \alpha$ and $3 \beta$ isomers of $5 \alpha$ androstanediol produced during the incubation was determined by adding $\left[{ }^{3} \mathrm{H}\right] 5 \alpha$-androstanediol $(11,000 \mathrm{cpm})$, produced by $5 \mathrm{~h}$ of incubation, to $3,500 \mathrm{cpm}$ of $\left[{ }^{14} \mathrm{C}\right]$ $5 \alpha$-androstan-3 $\beta, 17 \beta$-diol, prepared by reduction of $\left[{ }^{14} \mathrm{C}\right] \mathrm{DHT}$ with potassium borohydride (13). This mixture was then crystallized to constant isotopic ratio with authentic $5 \alpha$ androstan- $3 \beta, 17 \beta$-diol.

Polyacrylamide gel electrophoresis (PAGE). Analytical PAGE was performed at $0^{\circ} \mathrm{C}$ in gels of 6-14\% total gel concentration $(\% \mathrm{~T}), 2 \%$ cross-linking of methylene-bisacrylamide $(\% \mathrm{C})$, with multiphasic buffer system $\mathrm{D}, \mathrm{pH} 7.8$, as previously described $(14,15)$. Stacking gels of 3.125 $\% \mathrm{~T}, 20 \% \mathrm{C}$ were used. The "front" was marked with bromphenol blue. For determining the apparent $K_{d}$ and binding capacity, $\left[{ }^{3} \mathrm{H}\right] \mathrm{DHT}$ was added to the polymerization mixture to a final concentration of $15 \mathrm{nM}$ for the stacking and $2 \mathrm{nM}$ for the resolving gels as described by Weddington et al. (3).

Gels were sliced into $1 \pm 0.2 \mathrm{~mm}$ sections (16), placed into $10 \mathrm{ml}$ of LSC complete scintillation fluid, and counted in a liquid scintillation counter.

Relative mobility $\left(R_{f}\right)$ of labeled protein was calculated as the ratio of the migration distances of the peak of radioactivity and the "front". Retardation coefficient $\left(\mathrm{K}_{\mathrm{R}}\right), y$ intercept on the Ferguson plot $\left(\mathrm{Y}_{0}\right)$, and the joint $95 \%$ confidence envelopes of $\mathrm{K}_{\mathrm{R}}-\mathrm{Y}_{0}$ were computed as described $(15,17)$. The envelopes plotted semilogarithmically appear as ellipses (designated as " $K_{R}-Y_{0}$ ellipses") the centroids of which represent the experimentally determined size $\left(K_{R}\right)$ and net charge $\left(Y_{0}\right)$ of the given protein. The envelope circumscribes the values of $K_{R}$ and $Y_{0}$ that a molecule can assume with $95 \%$ confidence. Non-overlap of any two ellipses implies that two molecules are distinguishable with $P<0.05$. Nonoverlapping ellipses aligned along the " $K_{R}$ abscissa" describe molecules with different size but the same net charge density. They are designated as "size isomers" (18). Ellipses aligned along the $\mathrm{Y}_{0}$ ordinate represent molecules of the same size but different net charge. These are designated as "charge isomers" (18). The values of geometric mean radius and molecular weight (mol wt), derived from $K_{k}$, and of valence (net protons per molecule), derived from $\mathrm{Y}_{0}$ and geometric mean radius, were computed as described previously $(15,17)$.

The reproducibility of the $K_{R}-Y_{0}$ ellipses was determined by reanalysis of 10 specimens. The ellipses produced on the reanalysis were indistinguishable from the original ellipses in nine cases. Thus, there is a $10 \%$ chance that nonoverlap is due to interassay variation.

Isoelectric focusing in polyacrylamide gel (IFPA). Iso- 
electric focusing was performed as previously described (19), with the following modifications. An apparatus designed for IFPA was used (20). IFPA was performed at $4^{\circ} \mathrm{C}$ and $22^{\circ} \mathrm{C}$. Ampholine (LKB Produkter, Bromma, Sweden) at a final concentration of $1 \%$ in the $\mathrm{pI}^{\prime}$ ranges $3-10,4-6$, and 5-7 was employed. Gel concentrations for IFPA were selected by arbitrarily setting $\% \mathrm{~T}$ at a value providing mechanical stability $(6 \% \mathrm{~T})$. The $\% \mathrm{C}$ was increased until an $R_{f}=1.0$ for TeBG was obtained (20). A gel concentration of $6 \% \mathrm{~T}$, $30 \% \mathrm{C}$ was selected on this basis. Since the highly crosslinked gels exhibited poor wall adherence properties, tubes were coated with $1 \%$ Gelamide 250 (American Cyanamide Co., Linden, N. J.) and supported with dialysis membrane (21). Hemoglobin (pI' 7.05) and bovine serum albumin ( $\mathrm{pI}^{\prime}$ 4.8) with bound bromphenol blue were used as $\mathrm{pI}^{\prime}$ markers. A focusing time of $2 \mathrm{~h}$ was selected as the minimal time at which a constant $\mathrm{pI}^{\prime}$ value was reached. The lower electrolyte was $4.5 \%$ phosphoric acid and the upper electrolyte was $0.4 \%$ ethylenediamine. Gels were sliced as in PAGE and the slices suspended for $18 \mathrm{~h}$ in $0.02 \mathrm{M}$ $\mathrm{KCl}$ before $\mathrm{pH}$ determinations were made. $10 \mathrm{ml}$ of scintillation fluid was added to the suspensions and the radioactivity was measured as above.

Determination of apparent dissociation constant and binding capacity by steady-state PAGE (22) (Scatchardtype analysis). The apparent dissociation constant $\left(K_{d}\right)$ and binding capacity were determined in duplicate by Scatchard-type analysis by the procedure of Ritzen et al. (22). This procedure allows analysis of $K_{d}$ and binding capacity of the specific protein $(s)$ of interest. Charcoalextracted supernatants were loaded onto gels polymerized in the presence of $\left[{ }^{3} \mathrm{H}\right] \mathrm{DHT}$. The samples were incubated with variable amounts of nonradioactive DHT. At the steady state, the amount of $\left[{ }^{3} \mathrm{H}\right] \mathrm{DHT}$ bound is proportional to the area under the peak and the amount free is proportional to the area of the base of the peak. Areas were determined by computer. The amount free calculated in this manner did not differ from that calculated as described by Ritzén et al. (22).

Binding specificity studies performed in PAGE. For determination of the steroid-binding specificity, gels of $10 \% \mathrm{~T}, 2$ $\% \mathrm{C}$ were used and peak areas calculated by computer. 400 $\mu \mathrm{g}$ of plasma or testicular cytosol protein was incubated with $5 \mathrm{nM}\left[{ }^{3} \mathrm{H}\right] \mathrm{DHT}$ with and without 1,000-fold molar excess of a nonradioactive competing steroid. The "relative displaceability" of the steroid was calculated as follows: $\%$ displaceability $=[(A-B) / A] \times 100$, where $A$ is peak area of cytosol (or plasma) incubated with $\left[{ }^{3} \mathrm{H}\right] \mathrm{DHT}$; and $B$ is peak area of cytosol (or plasma) incubated with $\left[{ }^{3} \mathrm{H}\right] \mathrm{DHT}$ and 1,000-fold molar excess of competing steroid. The ability of each steroid to displace $\left[{ }^{3} \mathrm{H}\right] \mathrm{DHT}$ from cytosol of plasma binding proteins was performed in quadruplicate and compared to nonradioactive DHT with Student's $t$ test.

Collection of intratubular fluid by micropuncture. Male Sprague-Dawley rats, weighing from 300 to $350 \mathrm{~g}$, were anesthetized with $100 \mathrm{mg} / \mathrm{kg}$ body wt of sodium 5-ethyl-5(1methyl propyl)-2-thiobarbiturate (Inactin, Promonta, Hamburg, W. Germany) injected intraperitoneally. Micropipettes were prepared as previously described (23). The pipette tips were sharpened to a final diameter of $120-150 \mu \mathrm{M}$.

The testis and epididymis were approached through a scrotal incision and were bathed with water-equilibrated mineral oil to prevent surface dehydration. The tunica albuginea and epididymal capsule were slit to expose the tubules for micropuncture. Under 10-20× magnification, with a Nikon stereo zoom microscope (Nikon Inc., Instrument Group, Garden City, N. Y.), the micropipette was guided into the tubule with a Leitz micromanipulator (E. Leitz, Inc.,

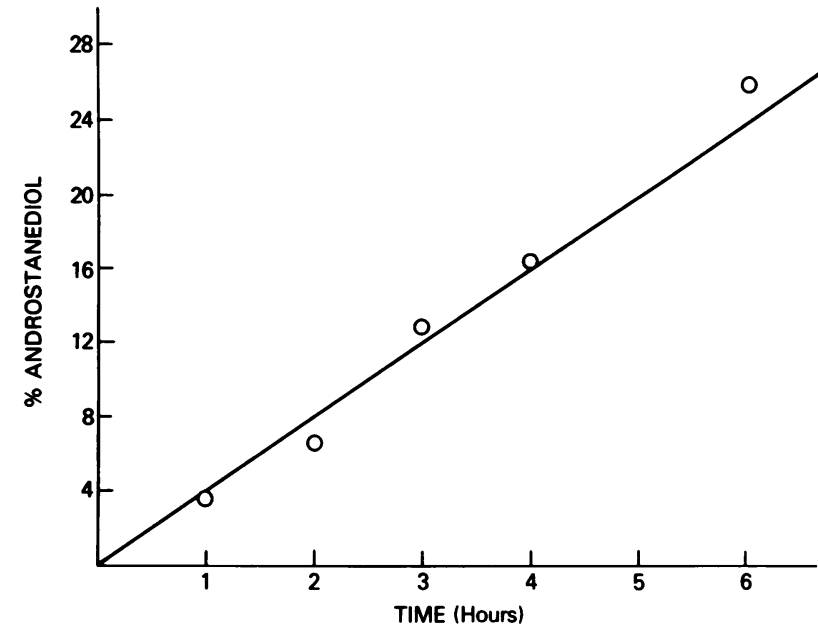

FIgURE 1 Metabolism of DHT to $5 \alpha$-androstanediol. Human testicular cytosol is incubated with $\left[{ }^{3} \mathrm{H}\right] \mathrm{DHT}$ and the percent of total counts converted to $\left[{ }^{3} \mathrm{H}\right] 5 \alpha$-androstanediol each hour is determined by thin layer chromatography (benzene:ethyl acetate::1:9).

Rockleigh, N. J.). A small drop of water-equilibrated mineral oil colored with Sudan black was injected to confirm the intraluminal location of the tip. Samples of 150-300 nl were aspirated from the seminiferous tubules and proximal epididymis, pooled, and stored under oil at $0^{\circ} \mathrm{C}$ until analyzed. In those animals from which rete testis fluid was collected, the ductuli efferentes were ligated $2 \mathrm{~h}$ before micropuncture of the rete testis. Individual samples of $0.5-30 \mu \mathrm{l}$ were obtained and treated as outlined above. Intraluminal aspirates were centrifuged at $13,000 \mathrm{~g}$ for $15 \mathrm{~min}$ in a microcapillary centrifuge (International Model MB, Damon/IEC, Needham Heights, Mass.). The supernatant was diluted in $100 \mathrm{vol}$ of $10 \mathrm{mM}$ Tris-chloride buffer, $\mathrm{pH} 7.4$.

Collection of monkey rete testis fluid (RTF). A modification of the procedure as described by Waites and EinerJensen was used (24). The testis and epididymis were exposed through a suprapubic incision under sterile conditions. The ductuli efferentes were identified and ligated, with care to avoid injury to the adjoining veins. The testis and epididymis were replaced in the scrotum and the incision was closed. $24 \mathrm{~h}$ later the animals were reanesthetized, the testis and epididymis were exposed, a 27-gauge needle was inserted through the capsule, and RTF was withdrawn without blood contamination. To exclude the possibility that the aspirated fluid was lymph, each sample was examined under light microscopy and found to have motile sperm too numerous to count. No red blood cells were visible in any of the aspirates. The aspirates were diluted with $10 \mathrm{vol}$ of $10 \mathrm{mM}$ Tris-chloride buffer $\mathrm{pH} 7.4$, incubated with charcoal, and treated as cytosol. Appproximately $400 \mu \mathrm{g}$ of RTF protein was added to each gel. A 200- $\mu$ l aliquot of RTF was not diluted or exposed to charcoal, and applied directly to the gel.

\section{RESULTS}

A high-affinity binding protein for DHT was found in the cytosol of human, monkey, and rat testis and epididymis and in the fluid obtained by micropuncture of rat seminiferous tubules, rete testis, and caput epi- 


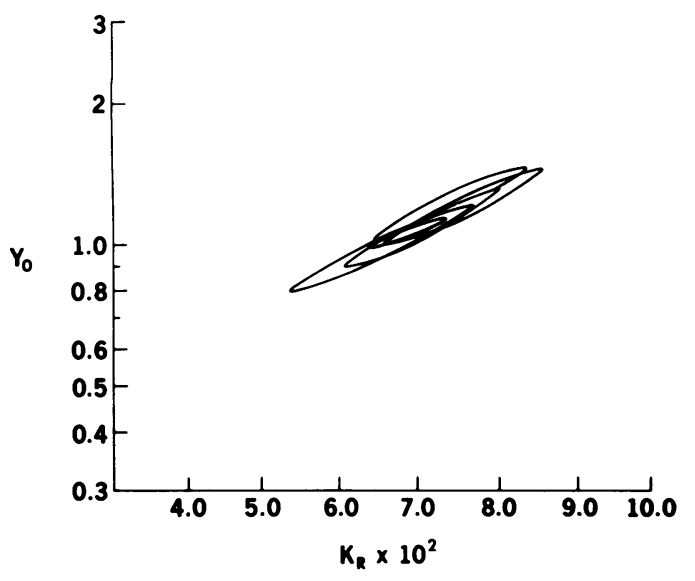

FIGURE 2 Joint $95 \%$ confidence envelopes of $K_{R}$ and $Y_{0}$ in PAGE (pH 7.8) for human TeBG obtained from five normal subjects.

didymis. In all cases, the low-affinity, high-capacity binding protein, albumin, was recognized by its characteristic $R_{f}$ in PAGE and neglected for the purposes of the study. No binding of $\left[{ }^{3} \mathrm{H}\right] \mathrm{DHT}$ was detected in the rete testis fluid of the three monkeys.

\section{Metabolism of DHT to androstanediol by cytosol}

The percent conversion of DHT to $5 \alpha$-androstanediol by testicular cytosol increased linearly with time (Fig. 1). Under the conditions of the incubations $(1 \mathrm{~h})$, the conversion was less than $4 \%$. If the time of electrophoresis is included $(90-120 \mathrm{~min})$, the conversion is approximately $10 \%$. The $5 \alpha$-androstanediol thus produced was composed of both the $3 \beta(66 \%)$ and $3 \alpha(34 \%$ isomers. The recovery of radioactivity was $92 \%$.

\section{Disctinction between human $A B P$ and $T e B G$}

PAGE. The physical properties of size $\left(\mathrm{K}_{\mathrm{R}}\right)$ and net charge $\left(Y_{0}\right)$ of human TeBG's from five normal subjects were compared. The $K_{R}-Y_{0}$ ellipses derived for the single plasma DHT-binding protein in these subjects overlap, suggesting the homogeneity of TeBG (Fig. 2). They also coincide with those obtained by Corvol et al. (14).

13 tissues from 9 patients were analyzed (Table I). Human ABP was found in 10 tissues from 7 of the patients. The $K_{R}-Y_{0}$ ellipses derived from

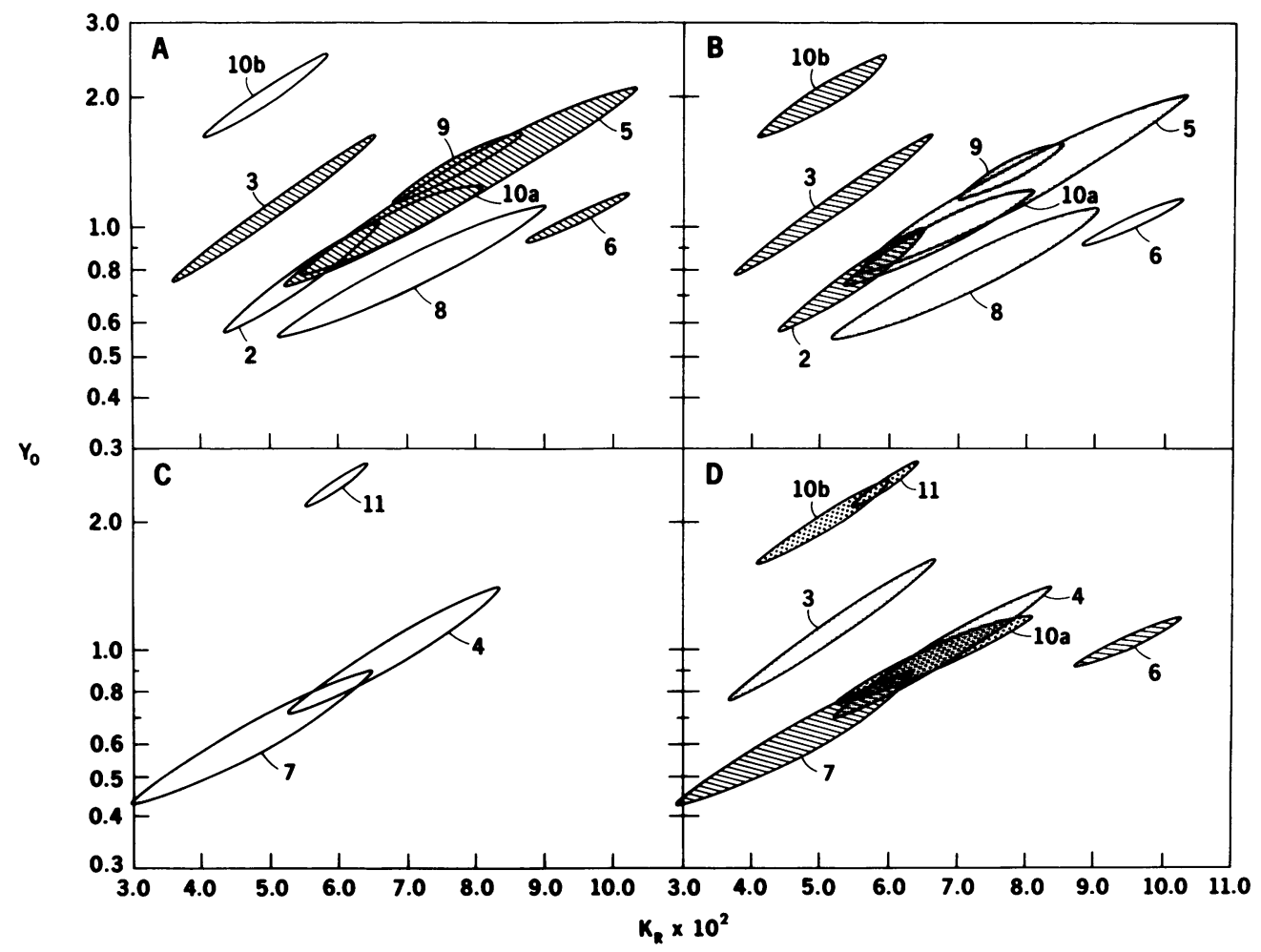

FIGURE 3 Joint 95\% confidence envelopes of $\mathrm{K}_{\mathrm{R}}$ and $\mathrm{Y}_{0}$ in PAGE ( $\mathrm{pH}$ 7.8) for human ABP (numbers correspond to Table I). A. Testicular ABP's; shaded ellipses are size isomers; B. testicular ABP's; shaded ellipses are charge isomers; C. epididymal ABP's; D. epididymal and testicular ABP's from R. S. (3 and 4), W. D. (6 and 7), and M. M. (10a, $10 \mathrm{~b}$, and 11). 
TABLE II

Apparent Dissociation Constant and Binding Capacity in Steady-State PAGE

\begin{tabular}{lcc}
\hline & $K_{d}( \pm \mathrm{SD})$ & Binding capacity \\
\hline & $n M /$ iter & pmollmg protein \\
Human ABP & $0.86 \pm 0.24$ & 0.26 \\
Human TeBG & $1.82 \pm 0.38$ & 1.20 \\
\hline
\end{tabular}

the Ferguson plots of these tissues are shown in Fig. 3. It is seen that: (a) four testicular species are distinct (ellipses 3,6, 8, and 10b) and four testicular species are indistinguishable from each other (ellipses 2, 5, 9, and 10a) (Fig. 3a); (b) five testicular species are related to each other as size isomers $(3,5,6,9$, 10a) and seven species are related to each other as two sets of charge isomers $(2,3,10 \mathrm{~b}$ and $5,8,9,10 \mathrm{a})$ (Fig. $3 a$ and $b$ ); $(c)$ two of the three epididymal species overlap $(4,7)$ (Fig. $3 c$ ); $(d)$ in the three patients from whom both testis and epididymis specimens were obtained, the ABP's are distinct in the two tissues ( 3 and 4; 6 and 7; 10a and 11). All species in these three patients can be related to each other as either charge or size isomers (Fig. $3 d) ;(e)$ when all epididymal and testicular species are compared to TeBG (not shown), three species are indistinguishable from TeBG $(4,5,9)$ and seven are distinguishable $(2,3,6,7,8,10 \mathrm{a}, 10 \mathrm{~b})$. In a small testis biopsy from a patient with Sertoli Cell only syndrome (W.S.) (200 mg tissue, wet wt) and one testis and epididymis specimen (H.J., stored for $24 \mathrm{~h}$ before analysis), ABP could not be detected.

To test the possible effect of the preparative process on human TeBG, rat testes were injected by multiple pucture with a 27 -gauge needle, in vivo, with $1 \mathrm{ml}$ of human plasma/testis. After $2 \mathrm{~h}$ the rats were sacrificed and a testicular cytosol was prepared. Simultaneous Ferguson plots run on the cytosol-containing plasma and on the plasma alone showed no change in the "native" human TeBG ellipse.

IFPA. Human TeBG and two human ABP species, one distinct from $\mathrm{TeBG}$ and the other indistinguishable from TeBG on the basis of ellipse criteria, were compared by IFPA. TeBG exhibited two isoelectric species, with pI's (mean \pm SD) of $6.1 \pm 0.4$ and $3.9 \pm 0.7$ $(n=32)$. Both ABP preparations exhibited the $\mathrm{pI}^{\prime}$ of 3.9 but the species indistinguishable from TeBG in PAGE did not reveal the second $\mathrm{pI}^{\prime}$ of 6.1 , while the species distinguishable from TeBG had both pI's.

Scatchard-type analysis. Pooled testis supernatants were compared to human TeBG by Scatchardtype analysis in steady-state PAGE. There was no significant difference $(P>0.10)$ between $\mathrm{ABP}$ and TeBG on the basis of dissociation constants. However, binding capacity per milligram of protein was approximately five times higher for hTeBG (Table II).

Steroid specificity. The mean \pm SD effect of 1,000 fold molar excess of DHT, testosterone, 17 $\beta$-estradiol, progesterone, $17 \alpha$-hydroxyprogesterone, dehydroepiandrosterone, dehydroepiandrosterone sulfate, androstenedione, and cortisol in displacing $\left[{ }^{3} \mathrm{H}\right]-$ DHT from either plasma (TeBG) or cytosol (ABP) is shown in Fig. 4. Under the conditions of this study, these binding proteins cannot be distinguished by a difference in displaceability of $\left[{ }^{3} \mathrm{H}\right] \mathrm{DHT}$ by any of the steorids tested $(P>0.05)$.

\section{Distinction of monkey $A B P$ and TeBG in PAGE}

Testis and epididymis homogenates from two monkeys were compared to TeBG by ellipse critiera (Fig. 5). It is seen that: (a) the ABP's from the two epididymis extracts ( 1 and 5$)$ are indistinguishable; (b) the testis estract ABP's (2 and 4) are distinguishable, but the two species can be related to one another as charge isomers; $(c)$ binding proteins from serum and epididymis extracts yield indistinguishable ellipses; $(d)$ the species derived from testes are smaller than those derived from either serum or epididymis, with species 4 being a size isomer of species 1,3 , and 5 .

\section{Detection of $A B P$ by micropuncture in rat and monkey}

Between five and eight times more protein was necessary to detect rat $\mathrm{ABP}$ in the seminiferous tubules when compared to caput epididymis and rete

שTTeBG $\square$ ABP

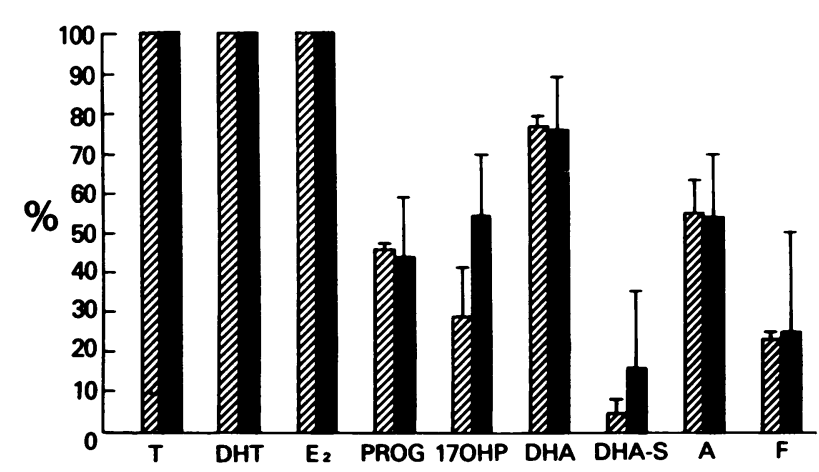

FIgUre 4 The mean \pm SD displacement of $\left[{ }^{3} \mathrm{H}\right] \mathrm{DHT}$ from testicular ABP and plasma TeBG by 1,000 -fold molar excess of DHT, testosterone $(\mathrm{T}), 17 \beta$-estradiol $\left(\mathrm{E}_{2}\right)$, progesterone (PROG), $17 \alpha$-hydroxyprogesterone (17OHP), dehydroepiandrosterone (DHA), dehydroepiandrosterone (A), and corti$\operatorname{sol}(\mathrm{F})$. 


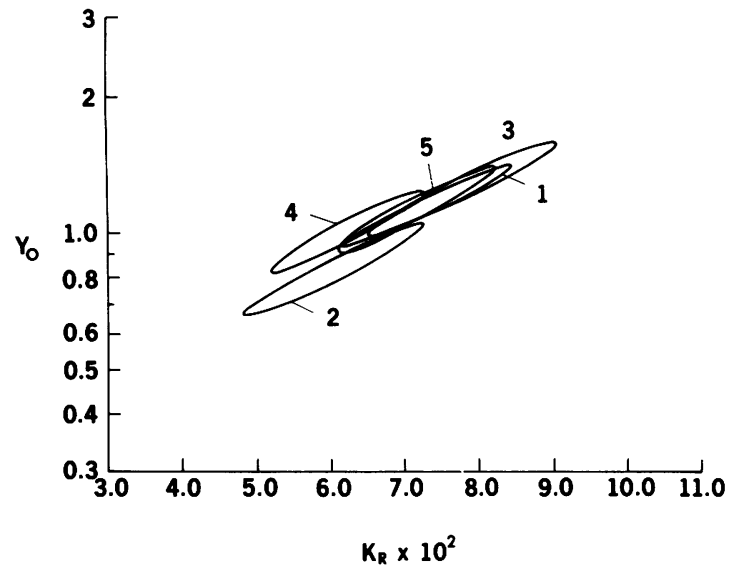

FigURE 5 Joint $95 \%$ confidence envelopes of $\mathrm{K}_{\mathrm{R}}$ and $\mathrm{Y}_{0}$ in PAGE ( $\mathrm{pH} 7.8)$ for monkey ABP for testis $(2,4)$ and epididymis $(1,5)$, and for monkey TeBG (3).

testis (Table III). Rat ABP was detected in 0.3 $\mu \mathrm{l}(67 \mu \mathrm{g})$ of caput epididymis fluid.

40,50 , and $400 \mu \mathrm{l}$ of blood-free RTF were obtained from three adult rhesus monkeys. Blood-contaminated fluid was obtained in an additional three monkeys. The mean \pm SD protein concentration of monkey RTF was 9 $\pm 3 \mathrm{mg} / \mathrm{ml}$. There was no detectable ABP in any of the monkey RTF samples. In one experiment, $200 \mu \mathrm{l}$ of RTF (1.8 mg of protein) undiluted by buffer was examined for the presence of $\mathrm{ABP}$ and none was found.

\section{Physical distinction between rat epididymal $A B P$ and TeBG in PAGE}

Rat epididymal ABP obtained by both micropuncture and tissue homogenization and TeBG are distin-

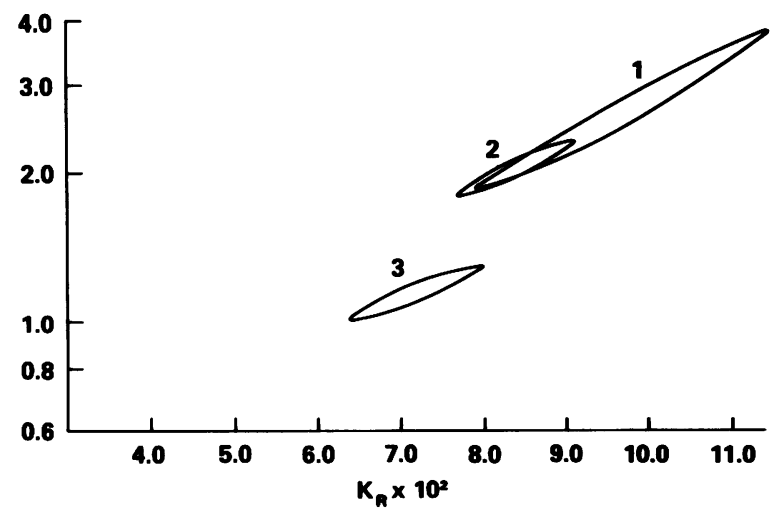

FIGURE 6 Joint $95 \%$ confidence envelopes of $\mathrm{K}_{\mathrm{R}}$ and $\mathrm{Y}_{0}$ in PAGE, system $\mathrm{D}, \mathrm{pH} 7.8,0^{\circ} \mathrm{C}$ for $\mathrm{ABP}$ in cytosol of rat epididymal homogenate (1), and $\mathrm{ABP}$ from sperm-free fluid obtained by epididymal micropuncture (2). The $\mathrm{K}_{\mathrm{R}^{-}}$ $Y_{0}$ envelope for human TeBG for a normal man (3) is included for comparison.
TABLE III

Minimum Total Protein and Volume of Sperm-Free Fluid for Detection of Rat ABP

\begin{tabular}{lccc}
\hline \multicolumn{1}{c}{ Source } & $\begin{array}{c}\text { Protein } \\
\text { concentration }\end{array}$ & Volume & $\begin{array}{c}\text { Total } \\
\text { protein }\end{array}$ \\
\hline Seminiferous tubule & $m g / m l$ & $\mu l$ & $\mu g$ \\
Rete testis & 52 & 7 & 364 \\
Caput epididymis & 9 & 5 & 45 \\
& 225 & 0.3 & 67 \\
\hline
\end{tabular}

guishable by the critera of nonoverlapping $95 \%$ confidence envelopes of $K_{R}$ and $Y_{0}$ in PAGE (Fig. 6). Parameters of molecular weight and net charge for both proteins derived from $K_{\mathrm{R}}$ and $\mathrm{Y}_{0}$ are indicated in Table IV.

\section{DISCUSSION}

Human ABP. Previous analysis by $\mathrm{PAGE}^{2}$ recognized only a single binding protein component in the testis of nonprimates, indistinguishable from $\mathrm{TeBG}$ $(4,7,25)$. In contrast, using PAGE at a $\mathrm{pH}$ of 7.8 , $0^{\circ} \mathrm{C}$, and a wide range of gel concentrations, we were able to recognize, in both monkey and human, multiple species of DHT-binding proteins (which appear related to each other as size and charge isomers) but only one species of human and monkey TeBG.

Five of eight of the testicular proteins appear to be members of an oligomeric series characterized by a common molecular net charge $(y \text {-intercept })^{3}$ and seven of eight of the testicular proteins are related to each other as two sets of charge isomers. Such isomerism is not surprising in view of the frequency of ligand gain or loss or hydrolytic reactions such as deamidation.

The cause of such heterogeneity is unclear. It does not appear to be due to variable tissue histories and storage times, since this polymorphism was also present with monkey ABP obtained under uniform conditions and analyzed without delay. Furthermore, in the three patients where both testis and epididymis were available for analysis, the ABP's from the two tissues were different by the criteria of PAGE (Fig. 3). Each individual patient's tissues were obtained under identical conditions. Thus, only one (if any)

${ }^{2}$ PAGE conditions were: $\mathrm{pH} 10.2$ at $0^{\circ} \mathrm{C}$ (corresponding to the setting of $\mathrm{pH} 8.9$ at $25^{\circ} \mathrm{C}$ in the Tris-glycine buffer system) and gels of 5.2 and $8.2 \%$ total gel concentration ( $3 \%$ cross-linking).

3 To assess the significance of a common $y$-intercept, a random assortment of 11 standard proteins was tested by the same criteria. Such isomerism was found with three proteins. 
TABLE IV

Physical Characteristics of Rat ABP and Human TeBG in PAGE

\begin{tabular}{lccccc}
\hline \multicolumn{1}{c}{ Material } & $\mathrm{K}_{\mathrm{R}} \times 10^{2}$ & \multicolumn{1}{c}{$\mathrm{Y}_{\mathrm{o}}$} & Radius & Mol wt* & Valence \\
\hline & & & & & $\begin{array}{c}\text { net protons/ } \\
\text { molecule }\end{array}$ \\
Human TeBG & & & & & -5.6 \\
Rat epididymis (homogenate) & $8.4 \pm 0.4$ & $2.1 \pm 0.16$ & 3.4 & 133,800 & -4.8 \\
Rat epididymis (micropuncture) & $9.7 \pm 0.6$ & $2.6 \pm 0.41$ & 3.8 & 184.300 & -15.9 \\
\hline
\end{tabular}

* Molecular weight estimates are based on the following standard proteins in $\sqrt{\mathrm{K}_{\mathrm{R}}} \mathrm{vs}$. $\sqrt[3]{\text { mol wt }}(15)$. Soybean trypsin I $(22,700)$; ovalbumin $(43,500)$; bovine serum albuminmonomer $(67,000)$; transferrin $(290,000)$; bacitracin $(1,411)$; ferritin $(450,000)$; glucagon $(3,485)$.

\$ Mean \pm 1 SD.

of the binding proteins could be intact TeBG in a given patient. Finally, since the size or charge of human TeBG are not changed during the preparation and analysis of rat testicular cytosol, it is not likely that the human ABP polymorphism is an artifact of the technique.

In attempting to differentiate human $\mathrm{ABP}$ and $\mathrm{TeBG}$ on the basis of other physicochemical parameters, we were unable to separate them reliably on the basis of different isoelectric points, steroid specificities, or dissociation constants. With respect to the last parameter, conversion of DHT to either the $3 \alpha$ or $3 \beta$ isomer of $5 \alpha$-androstanediol is $10 \%$ or less under the experimental conditions. The $3 \beta$ metabolite does not bind to ABP (unpublished data), and is not a biologically active androgen. Thus, the minimal conversion of DHT does not alter the interpretation that the $K_{d}$ 's of human ABP and TeBG are indistinguishable.

Monkey ABP. The results obtained from analysis of monkey testis and epididymis are similar to those found in humans. However, by a modification of the Waites technique, it was possible to obtain blood-free fluid from the rete testis. In all three monkeys where this was accomplished, ABP was not detectable, whereas ABP was detectable in rat RTF under similar experimental conditions and in considerably smaller volumes. The detection of $\mathrm{ABP}$ in the cytosol of the same monkeys' testes but not in their RTF suggests that what is being analyzed and called ABP is really TeBG in various stages of degradation.

Rat $A B P$. The data show that $\mathrm{ABP}$ from the rat and TeBG from a human can be physically differentiated by the PAGE system as described above. Rat ABP has a mean molecular radius of $3.4 \mathrm{~nm}$ and a mol wt of 133,800 while TeBG has a radius of $3.0 \mathrm{~nm}$ and a mol wt of 94,100 . The values for TeBG agree with those found by Corvol et al. (14) but the values for rat $\mathrm{ABP}$ differ from those previously reported (4, 5 ) because fewer gel concentrations were used to construct the Ferguson plot (and presumably fewer pro- teins were used to construct the standard curve for calculating mol wt and radius) than were employed in this study.

Does $A B P$ exist in primates? While there is no doubt that $\mathrm{ABP}$ exists in the rat (a species that lacks TeBG), it would appear that in primates, ABP cannot be found as a molecule distinguishable from TeBG. What is found in human and monkey cytosol is a family of size and charge isomers that bind DHT but are indistinguishable from TeBG on the basis of other physicochemical parameters. Furthermore, ABP is not detectable in monkey RTF. The possibility still exists, however, that human or monkey ABP may exist within the seminiferous tubules and be (a) degraded before entering the rete testis; or (b) transported via extratubular means to the epididymis. These possibilities seem less tenable in view of the detection of $A B P$ in the rat seminiferous tubule, rete testis, and epididymis. Just as extrapolating findings in the rat to man is hazardous, similar caution must be taken when data in the monkey is applied to man. Thus, the absence of $A B P$ in monkey RTF does not totally exclude the possibility of its presence in man.

\section{ACKNOWLEDGMENTS}

We would like to thank Dr. David Rodbard for assistance in the use of his computer program. We would also like to acknowledge the assistance of Dr. Roger Johnsonbaugh, for providing some of the human specimens, and the technical assistance of Ms. Sandra Jessee and Ms. Anne Johnson for providing the micropuncture samples.

\section{REFERENCES}

1. Hansson, V., E. M. Ritzén, F. S. French, and S. N Nayfeh. 1975. Androgen transport and receptor mechanism in testis and epididymis. Handb. Physiol. Section 7 (Endocrinology). 5: 173-201.

2. French, F. S., and E. M. Ritzén. 1973. A high-affinity androgen-binding protein $(\mathrm{ABP})$ in rat testis: evidence for secretion into efferent duct fluid and absorption by epididymis. Endocrinology. 93: 88-95. 
3. Weddington, S. C., WV. S. McLean, S. N. Narfeh, F. S. French, V. Hansson, and E. M. Ritzen. 1974. Androgen binding protein (ABP) in rabbit testis and epididrmis. Steroids. 24: 123-134.

4. Ritzén, E. M., M. C. Dobbins, D. J. Tindall, R. S. French, and S. N. Nayfeh. 1973. Characterization of an androgen binding protein $(A B P)$ in rat testis and epididrmis. Steroids. 2: 593-608.

5. Hansson, V. 1972. Further characterization of the $5 \alpha$ dihydrotestosterone binding protein in the epididymal crtosol fraction. In vitro studies. Steroids. 20: 575-596.

6. Corrol, P., and C. WV. Bardin. 1973. Species distribution of testosterone-binding globulin. Biol. Reprod. 8: $277-282$.

7. Hansson, V., M. E. Ritzen, F. S. French, S. C. Weddington, and S. N. Nayfeh. 1975. Testicular androgen-binding protein (ABP): Comparison of $\mathrm{ABP}$ in rabbit testis and epididymis with a similar androgen-binding protein (TeBG) in rabbit serum. Mol. Cell Endocrinol. 3: 1-20.

8. Lowry, O. H., N. J. Rosebrough, A. L. Farr, and R. J. Randall. 1951. Protein measurement with the Folin phenol reagent. J. Biol. Chem. 193: 265-275.

9. Heyns, W., H. Van Baelen, and P. De Moor. 1967. Study of steroid-protein binding by means of competitive adsorption: application to cortisol binding in plasma. Clin. Chem. Acta. 18: 361-370.

10. Hansson, Y., O., Djoseland, E. Reusch, A. Attramadal, and O. Torgessen. 1973. Intracellular receptors for $5 \alpha$ dihydrotestosterone in the epididymis of adult rats. Comparison with the androgen receptors in the ventral prostate and the androgen binding protein (ABP) in the testicular and epididymal fluid. Steroids. 22: 19-33.

11. Tindall, D. J., V'. Hansson, S. C. Weddington, F. S. French, and S. N. Nayfeh. 1973. Androgen binding to cytoplasmic and nuclear receptors in rat epididymis in vivo. Demonstration of nuclear uptake in the absence of testicular androgen binding protein (ABP). Endocrinology. 92: A-128. (Abstr.).

12. Tindall, D. J., V. Hansson, W. S. McLean, S. N. Nayfeh, and F. S. French. 1975. Androgen binding proteins in rat epididymis. Characterization of the cytoplasmic receptor in comparison with intraluminal androgen binding protein $(\mathrm{ABP})$ and the crtoplasmic receptor of rat ventral prostate. Mol. Cell. Endocrinol. 3: 83-101.

13. Elisberg, E., H. Vanderhaeghe, and T. F. Gallagher. 1952. Preparation of $3 \alpha$-hydroxyetiocholane-17-one by a differential reduction with sodium borohydride. J. Am. Chem. Soc. 74: 2814-2816.
14. Corvol, P. L., A. Chrambach, D. Rodbard, and C. W. Bardin. 1971. Physical properties and binding capacity of testosterone-estradiol-binding globulin in human plasma, determined by polyacrylamide gel electrophoresis. J. Biol. Chem. 246: 3435-3443.

15. Rodbard, D., and A. Chrambach. 1971. Estimation of molecular radius, free mobility, and valence using polyacrylamide gel electrophoresis. Anal. Biochem. 40: 95134.

16. Petersen, J. I., H. IV. Tipton, and A. Chrambach. 1974. A gel slicer for the transverse sectioning of cylindrical polyacrylamide gels. Anal. Biochem. 62: 274-280.

17. Rodbard, D., and A. Chrambach. 1974. Quantitative polyacrylamide gel electrophoresis: mathematical and statistical analysis of data. In Electrophoresis and Isoelectric Focusing in Polyacrylamide Gel. R. C. Allen and H. R. Mauerer, editors. Walter De Gruyter \& Co., Berlin, IV. Germany, 28-62.

18. Hedrick, J. L., and A. J. Smith. 1968. Size and charge isomer separation and estimation of molecular weights of proteins by disc gel electrophoresis. Arch. Biochem. Biophys. 126: 155-164.

19. Doerr, P., and A. Chrambach. 1971. Anti-estradiol antibodies: Isoelectric focusing in polyacrylamide gel. Anal. Biochem. 42: 96-107.

20. Chrambach, A., P. Doerr, G. R. Finlayson, L. E. M. Miles, R. Sherins, and D. Rodbard. 1973. Instability of $\mathrm{pH}$ gradients formed by isoelectric focusing in polyacrylamide gel. Ann. N. Y. Acad. Sci. 209: 44-64.

21. Finlayson, G. R., and A. Chrambach. 1971. Isoelectric focusing in polyacrylamide gel and its preparative application. Anal. Biochem. 40: 292-311.

22. Ritzén, E. M., F. S. French, S. C. Weddington, S. N. Nayfeh, and V. Hansson. 1974. Steroid binding in polyacrylamide gel. Quantiation at steady-state conditions. J. Biol. Chem. 249: 6597-6604.

23. Howards, S. S., A. Johnson, and S. Jessee. 1975. Micropuncture and microanalytic studies of the rat testis and epididymis, Fertil. Steril. 26: 13-19.

24. Waites, G. M. H., and N. Einer-Jensen. 1974. Collection and analysis of rete testis fluid from Macaque monkeys. J. Reprod. Fertil. 41: 505-508.

25. Hansson, V., E. M. Ritzen, F. S. French, S. C. Weddington, S. N. Nayfeh, E. Reusch, and A. Attramadal. 1973. Demonstration of a specific binding protein for testosterone and $5 \alpha$-dihydrotestosterone in rabbit serum. Separation from the corticosteroid binding globulin (CBG). Steroids. 22: 185-192. 